\title{
A GRAVITY MODEL OF TRADE TURNOVER BETWEEN UKRAINE AND THE EU
}

\author{
Tetyana Melnyk ${ }^{1}$, Nataliya Kalyuzhna², Kateryna Pugachevska ${ }^{3}$
}

\begin{abstract}
Determining the conditions for further liberalization and the reality of long-term and effective trade and economic cooperation of Ukraine with the EU countries requires assessing the strength and probability of the influence of institutional factors. The possibility of taking into account the significance of institutional factors in the development of foreign trade relations creates a gravity modelling. Determination of gravitational principles of foreign trade actualizes the problem of developing the gravity model, which takes into account impact of institutional factors, contains the necessary and sufficient number of factors, and may be tested for adequacy based on statistical data. The purpose of the paper is to construct the gravity model taking into account the institutional conditions of trade and its empirical verification on the example of trade turnover between Ukraine and the EU. Methodology. Methods of statistical analysis and econometric modelling were used for constructing the gravity model, estimating its statistical significance and predictive ability. In the article, the necessity of taking into account the influence of institutional factors on the formation of the competitive status of the country in the sphere of international trade is substantiated. It is proved that, in conditions of increasing the contradictory nature of trade relations, the role of institutional gravity factors in foreign trade between states increases. The result of the article is the gravity model with such explanatory factors, as the gross domestic product of trade partners in purchasing power parity and the complex characteristic of "trade distance" between countries as an indicator of the influence of institutional factors on foreign trade relations. As a conclusion, it may be noted that the model is statistically significant, adequately describes the input data. The proposed model takes into account the presence of institutional factors of foreign trade, whose influence on the interstate trade and economic cooperation conditions is constantly increasing. Value/originality. The proposed results can be used for modelling and forecasting of foreign trade between trading partners, taking into account the impact of specific institutional factors on their foreign trade relations.
\end{abstract}

Key words: foreign trade, liberalization, European Union, institutional factors, gravity model, export promotion.

JEL Classification: F12, F41, F47

\section{Introduction}

An important aspect of the present is to determine the integration vector of Ukraine's development, taking into account the peculiarities of the national economy and the possibilities of realizing its potential as a part of modern integration associations. Currently, the problems of developing the Ukrainian economy in the framework of European integration processes are at the centre of attention of many domestic scholars. Ukraine's progress on the path to European integration was affected by the implementation of the Association Agreement and, consequently, the liberalization of the trade regime with the EU in terms of administering the origin of goods and tariff regulators. At the same time, an attention should be paid to the presence of restraining institutional factors

\footnotetext{
Corresponding author:

${ }^{1}$ Kyiv National University of Trade and Economics, Ukraine.

E-mail: melnikknteu998@gmail.com

${ }^{2}$ Kyiv National University of Trade and Economics, Ukraine.

E-mail: kalujnaya.natalya@gmail.com

${ }^{3}$ Kyiv National University of Trade and Economics, Ukraine.

E-mail: kpugachevska@gmail.com
}

of bilateral foreign trade, which have been caused by rapid geopolitical transformations in the European and post-Soviet space. Under current conditions, the liberalization of foreign trade is increasingly determined not by economic expediency but by institutional factors for the development of bilateral relations between the countries.

The determination of the possibilities, conditions, and reality of long-term and effective trade and economic cooperation of Ukraine with the EU countries requires assessing the strength and probability of the influence of institutional factors on the course of foreign trade processes.

The possibility of taking into account the significance of institutional factors in the development of foreign 
trade relations creates a gravity modelling. Forming an adequate gravity model contributes to understanding the mechanisms and restrictions on foreign trade between partner countries, identifying factors that affect the volume and direction of trade flows.

The increasing importance of institutional factors in the development of foreign trade makes it necessary to consider them in the construction of the gravity model. At the same time, it is important not overburdening the model by a large number of factors, which usually leads to its statistical insignificance. Thus, there is a problem of constructing the gravity model, which takes into account the impact of institutional factors on foreign trade relations and contains the necessary and sufficient number of factors.

\section{Determinants of constructing gravitational models of external trade}

First gravity equation of foreign trade was formalized and empirically confirmed by J. Tinbergen (Tinbergen, 1966). Since then, a large number of gravity model specifications have been proposed. These specifications differ by a set of qualitative and quantitative factors of influence on foreign trade that should be taken into consideration. The most widely used gravity model specifications belong to $\mathrm{H}$. Linnemann (Linnemann, 1967), J. McCallum (McCallum, 1995), S. Baier \& J. Bergstrand (Baier \& Bergstrand, 2009). These models were further developed and nowadays serve as the basis for the formation by many domestic researchers of their own gravitational equations, as well as for testing hypotheses as for the prospects of mutual trade between certain countries (Konchyn et al, 2012; Nasadiuk, 2012; Poliakova \& Shlykova, 2014). In order to form their own gravity models, authors either follow the classic model shapes with a minimal number of gravity variables (Korovaichenko \& Shevchenko, 2015) including 1-3 dummies (Nasadiuk, 2012) or tend to maximize the number of factors in equations (Konchyn et al, 2012). The sharp increase in the significance of institutional factors in the development of the world economic system leads to the fact that researchers are trying to take into account the impact on foreign trade flows of various qualitative parameters. Essentially, the authors adhere primarily not to inductive but to deductive research methods. That is, there is a search with result known in advance, which later gets the econometric rationale, and expands understanding of the sources, perspectives, and limitations of foreign trade between countries.

The logic of building a gravity model of foreign trade is based on the idea of Newtonian gravity. Namely, the force of attraction between the objects is directly proportional to their masses and inversely proportional to the square of the distance between them. In the context of describing the interaction of economic agents (in particular, their bilateral trade), this idea is transformed into the following: the force of interaction between economic subjects (integration entities, countries, regions, etc.) is directly proportional to the product of their importance indicators (economic potential) and inversely proportional to their mutual remoteness. A gravity model of foreign trade traditionally is presented in a multiplicative form. Transformation of the model from multiplicative to log-linear form makes possible to apply multiple regression analysis methods.

Standard gravity explanatory variables, such as the economic significance of the objects and the distance between them, are presented both in classic and modern specifications of the gravity model. Usually, the gross domestic product (GDP) indicator measures the significance of objects in the gravity model. The approach to using GDP as a basic gravitation variable is followed by a majority of both foreign (Tinbergen, 1966; Linnemann, 1967; McCallum, 1995; Baier \& Bergstrand, 2009) and domestic (Nasadiuk, 2012; Poliakova \& Shlykova, 2014; Podorozhnii et al, 2018) researchers. It is also possible to include other factors that determine economic strength of countries into gravity model, such as gross income (McCallum, 1995), population (Tinbergen, 1966), or modifications of gross domestic product by calculation method GDP per capita (Konchyn et al, 2012), GDP calculated in international dollars (Korovaichenko \& Shevchenko, 2015).

In our opinion, it is reasonable to use the gross domestic product based on purchasing-power-parity (PPP) as a basic gravitational explanatory variable. This macroeconomic indicator calculated in international dollars reflects differences in costs of living in different countries and, therefore, is quite an accurate description of the economic development and economic growth of a particular country.

The distance between partners, usually interpreted as a geographical remoteness of their main economic centres (capitals), is another classic explanatory variable in gravity models of foreign trade. Clearly, transport costs affect foreign trade between partner countries, increasing or decreasing (depending on distance) their mutual turnover. In our view, it is reasonable to separate transportation costs arising from the geographical remoteness and those associated with other factors: the presence of trade barriers, bureaucratic obstacles, lack of adequate commercial infrastructure, high-risk economic activity, changes in the foreign policy of countries, etc. The impact of these indirect factors on bilateral trade in some cases can exceed the importance of geographical distance.

In particular, the current state of Ukrainian-Russian trade relations confirms that under actual geopolitical conditions, the geographical proximity is not a premise for a large volume of bilateral trade. Conversely, a beneficial foreign economic cooperation with geographically distant countries that are members of 
international integration entities with common political and security and/or economic goals (EU, CIS, NATO, BRICS, etc.) may be expected.

In this connection, it should also be pointed out that the tendency of protectionism and antiglobalism in the foreign policy of the world leaders is spreading nowadays. The active applying of economic pressure methods in international trade suggests that the intensity of the tension in foreign trade relations between the states-leaders of the world will tend to increase from contradictory situations in bilateral trade to the stage of trade and economic wars. Under such conditions, the priority in the formation of bilateral foreign trade relations between the states will be institutional factors, which confirms the necessity to consider them when constructing gravity models of foreign trade.

\section{Survey methodology}

It seems appropriate to define as a basic gravitational variable the complex characteristic of "trade distance" between partner countries with an expected significant negative coefficient. It is reasonable to use the yearly average oil price as a quantitative equivalent of "trade distance". The appropriate approach is realized, particularly by Korovaichenko, N. \& Shevchenko, L. (Korovaichenko \& Shevchenko, 2015) in modelling bilateral trade between Germany and Ukraine assuming that transport costs depend on fluctuations in oil prices. We think that the explanatory potential of the idea of using yearly oil prices as an indicator of "trade distance" between countries is much broader. Indeed, fluctuations in oil prices obviously affect the cost of international transporting. In this sense, oil price is a factor of direct impact on the value of "trade-distance". First, transport costs are proportionate to geographical remoteness of partner countries (static component), and secondly, the cost of traffic changes due to fluctuations in oil prices (dynamic component). On the other hand, the oil price can be considered as the factor of indirect impact on trade relations between partner countries, to be exact - an indicator of dynamics of institutional conditions of international and bilateral trade.

Based on the above, it is possible to offer the gravity model equation for foreign trade in goods between the two countries as follows:

$$
E_{i j}=\alpha_{0} Y_{i}^{\alpha_{1}} Y_{j}^{\alpha_{2}} D_{i j}^{\alpha_{3}} \eta_{i j} \text {, }
$$

where $E$ - bilateral turnover between countries;

$Y_{1}, Y_{2}$ - gross domestic products of countries in purchasing power parity (GDP in PPP);

$D$ - a complex characteristic of "trade distance" between countries, which quantitatively is equalled to yearly average oil price;

$\alpha_{0}, \alpha_{1}, \alpha_{2}, \alpha_{3}$ - estimated model parameters;

$\eta$ - the random term of the equation.

The gravity model of trade turnover between Ukraine and the EU may be suggested based on proposed factors.
The source data for the multiple regression model are as follows: gross domestic product of partners in purchasing power parity (International Monetary Fund, 2017), mutual trade turnover between the partners (State Statistics Service of Ukraine, 2017), and yearly average price for Brent crude (IndexMundi, 2017) in the 1996-2017 period.

The multiple regression equation can be constructed using logarithmic variables:

$\ln E=\ln \alpha_{0}+\alpha_{1} \ln Y_{1}+\alpha_{2} \ln Y_{2}+\alpha_{3} \ln D+\ln \eta$

The following notations are proposed:

$y=\ln E, x_{1}=\ln Y_{1}, x_{2}=\ln Y_{2}, x_{3}=\ln D$

In order to assess the validity of including the factors in the gravity model, it is necessary to determine a correlation between them (Table 1).

Table 1

The matrix of intercorrelations for the model

\begin{tabular}{|c|c|c|c|c|}
\hline & $\mathrm{x}_{1}$ & $\mathrm{x}_{2}$ & $\mathrm{x}_{3}$ & $\mathrm{y}$ \\
\hline $\mathrm{x}_{1}$ & 1 & 0,936 & 0,944 & 0,988 \\
\hline $\mathrm{x}_{2}$ & 0,936 & 1 & 0,852 & 0,923 \\
\hline $\mathrm{x}_{3}$ & 0,944 & 0,852 & 1 & 0,953 \\
\hline $\mathrm{y}$ & 0,988 & 0,923 & 0,953 & 1 \\
\hline
\end{tabular}

There is a strong positive correlation both between factors and result, as well as between factors, as shown in Table 1. There are standard approaches to overcome correlations between factors, such as exclusion from the model of one or more factors; transition to combined regression equations that take into account intercorrelations; a combination of both aforementioned approaches. Typically, several statistically significant models can be built based on input data.

The process of selecting the optimal model can be formalized using information criteria. The most popular information criteria are the Akaike criterion (AIC) and the Schwartz criterion (BIC), defined as:

$$
\begin{aligned}
& A I C=-2 \ln (L)+2 p \\
& B I C=-2 \ln (L)+\ln (n) p
\end{aligned}
$$

where $\ln (L)$ - log-likelihood function value;

$p$ - the number of assessed model parameters, including estimated variance;

$n$ - the number of observations.

The information criteria value decrease with increasing likelihood function value and increase with increasing number of model factors. The model with lower criteria value is considered as preferable, i.e. the one with higher likelihood function value and lower number of model factors. The introduction of new model factors is justified if it leads to a marked increase in the likelihood function value. The criteria AIC and BIC differ only way to take into account a complexity of the model (the second term on the right of expression (4)). Usually $\log (n)>2$, meaning the criterion BIC selects a simpler (more economical) model. 
The coefficients of determination and information criteria for 64 models that take into account all the possible interactions between factors $x_{1}, x_{2}, x_{3}$ were calculated. The expediency of calculating the adjusted coefficient of determination occurs due to comparability of the number of factors in the model and number of observations $(n=22)$.

Table 2 presents the results of calculating the coefficients of determination for models with the highest values of the criteria AIC and BIC. The minimum value both information criteria take for a set of factors $\left\{x_{3}, x_{1} x_{3}\right\}$, as shown in the table. At the same time, the values of coefficients of determination for the first six models are nearly identical and high enough.

So the model with a set of factors $\left\{x_{3}, x_{1} x_{3}\right\}$ should be considered as optimal one. This model takes into account the effect of the first order interaction between factors $x_{1}$ and $x_{3}$ and may be presented in a general form:

$$
y=c_{0}+c_{1} x_{3}+c_{2} x_{1} x_{3}
$$

The chosen model is consistent with the principle of efficiency, contains minimum sufficient number of factors, and does not include factor $x_{2}$ in the pure form. As shown in Table 1, there is a strong correlation between model factors. Therefore, the influence of factor $x_{2}$ on the target is taken into account through intercorrelations.

The model parameters can be determined using the least square method. The combined regression equation is:

$$
y=2.84607-3.27341 x_{3}+0.583 x_{1} x_{3}
$$

We estimate the statistical significance of regression equation parameters using the Student's t-test. In Table 3, P-Value is the probability that the t-statistic is higher than the resulting value. If $P-$ Value $\prec 0.05$, the hypothesis about statistical insignificance of regression equation parameter can be discarded. As one can see, this requirement is satisfied for all the three parameters, which means they are significantly different from zero.

The statistical significance of the multiple regression equation generally is measured using the Fisher test. In Table 4, P-Value is the probability that the F-statistic is higher than the resulting value. If $P$-Value $\prec 0.05$, the hypothesis concerning statistical insignificance regression equation can be discarded. A low P-Value indicates a statistically significant model.

\section{Findings}

Figure 1 plots the visual confirmation of the statistical significance of the regression equation comparing the output data with model predictions. As shown in Figure 1, the actual values of mutual trade turnover between Ukraine and the EU for the 1996-2017 are sufficiently consistent with the model predictions in the respective years. Thus, we can conclude that the proposed specification of gravity equation of foreign trade between Ukraine and the EU is statistically significant, adequately describes the source data, and can be used for modelling and forecasting of foreign relations between partners.

Table 2

Results of calculating the coefficients of determination and information criteria for selected models

\begin{tabular}{|c|c|c|c|c|}
\hline Model & $\begin{array}{c}\text { Coefficient of } \\
\text { determination }\end{array}$ & $\begin{array}{c}\text { Adjusted coefficient of } \\
\text { determination }\end{array}$ & AIC criterion & BIC criterion \\
\hline$\left\{\mathrm{x}_{3}, \mathrm{x}_{1} \mathrm{x}_{3}\right\}$ & 0,988505 & 0,987295 & $-47,0553$ & $-42,6911$ \\
\hline$\left\{\mathrm{x}_{1}, \mathrm{x}_{2}, \mathrm{x}_{3}, \mathrm{x}_{2} \mathrm{x}_{3}\right\}$ & 0,990532 & 0,988304 & $-47,3227$ & $-40,7765$ \\
\hline$\left\{\mathrm{x}_{3}, \mathrm{x}_{1} \mathrm{x}_{3}, \mathrm{x}_{2} \mathrm{x}_{3}\right\}$ & 0,989062 & 0,987239 & $-46,1485$ & $-40,6933$ \\
\hline$\left\{\mathrm{x}_{3}, \mathrm{x}_{1} \mathrm{x}_{2}, \mathrm{x}_{1} \mathrm{x}_{3}\right\}$ & 0,989017 & 0,987187 & $-46,0584$ & $-40,6032$ \\
\hline$\left\{\mathrm{x}_{2}, \mathrm{x}_{3}, \mathrm{x}_{1} \mathrm{x}_{3}\right\}$ & 0,988970 & 0,987131 & $-45,9631$ & $-40,5079$ \\
\hline$\left\{\mathrm{x}_{1}, \mathrm{x}_{3}, \mathrm{x}_{1} \mathrm{x}_{3}\right\}$ & 0,988643 & 0,986751 & $-45,3219$ & $-39,8667$ \\
\hline
\end{tabular}

Table 3

Statistical estimation of significance of parameter regression equation

\begin{tabular}{|c|c|c|c|c|}
\hline Parameter & Parameter estimation & Standard error & t-statistics & Probability level P-Value \\
\hline$c_{0}$ & 2,84607 & 0,301144 & 9,45086 & $1,2969 \times 10-8$ \\
\hline$c_{1}$ & $-3,27341$ & 0,363694 & $-9,00046$ & $2,79055 \times 10-8$ \\
\hline$c_{2}$ & 0,583399 & 0,050393 & 11,577 & $4,73833 \times 10-10$ \\
\hline
\end{tabular}

Table 4

Variance table for the multiple regression equation

\begin{tabular}{|c|c|c|c|c|c|}
\hline Variance & $\begin{array}{c}\text { Number of freedom } \\
\text { degrees }\end{array}$ & $\begin{array}{c}\text { Sum of squares of } \\
\text { deviations }\end{array}$ & $\begin{array}{c}\text { Sum of the squares } \\
\text { of deviations per one } \\
\text { degree of freedom }\end{array}$ & F-statistic & $\begin{array}{c}\text { Probability level } \\
\text { P-Value }\end{array}$ \\
\hline Factorial & 2 & 9,06952 & 4,53476 & 816,934 & $3,75749 \times 10-19$ \\
\hline Residual & 19 & 0,105468 & 0,00555095 & & \\
\hline Total & 21 & 9,17499 & & & \\
\hline
\end{tabular}




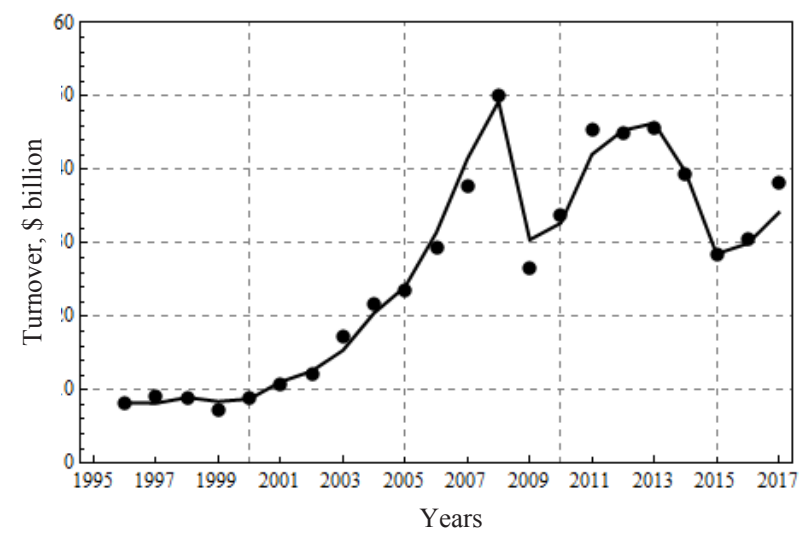

Figure 1. Comparison of actual turnover between Ukraine and the EU with model predictions

In order to test the predictive power of the model, we forecast trade turnover between Ukraine and the EU in 2018 , which can reach $\$ 34.4$ billion provided that the trend of the first quarter continues. According to the International Monetary Fund [9], the predictive value of Ukraine's GDP in PPP in 2018 is \$386.393 billion; the average Brent oil price for the year is expected near $\$ 68.3$ per barrel.

According to the proposed gravity model, the point forecast turnover between Ukraine and the EU in 2018 is equal to $\$ 40.4$ billion, which is $5.37 \%$ higher than its actual value in 2017. Note that the point forecast of trade turnover is probabilistic; its value will be corrected in accordance with the final results of 2018. An interval forecast provides a more complete picture about predictive ability of the model, according to which the trade turnover between Ukraine and the EU in 2018 will be in the range from $\$ 34.2$ to $\$ 47.8$ billion with a probability of $95 \%$, and will be in the range from $\$ 37.3$ to $\$ 43.7$ billion with a probability of $67 \%$ (standard error).

Figure 2 presents the actual trade turnover between Ukraine and the EU and its interval forecast for the 2018 year with a probability of $67 \%$. Obviously, the predictive ability of the model is at the appropriate level, and the expected value of trade between Ukraine and

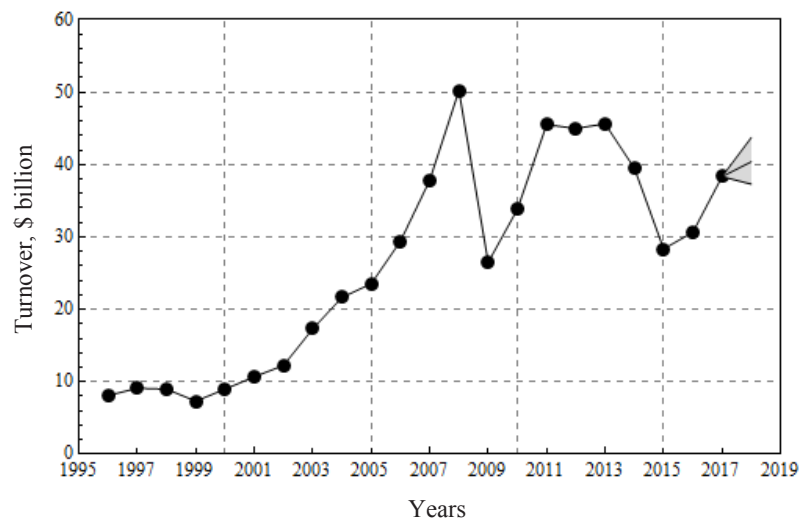

Figure 2. Actual trade turnover between Ukraine and the EU and interval forecast for 2018 (with a probability of 67\%)

the EU in 2018 ( $\$ 40.4$ billion) belongs to the calculated confidence interval.

\section{Conclusions}

Summarizing the experience of gravity modelling of trade relations allowed proposing the gravity model of foreign trade with such basic explanatory variables: the gross domestic product of the trade partners in purchasing power parity with expected positive significant impact; the complex characteristic of "trade distance" between the countries, which quantitatively is equalled to yearly average oil price. The proposed model takes into account the presence of institutional factors of foreign trade, whose influence on the interstate trade and economic cooperation conditions is constantly increasing.

Based on proposed factors, the gravity model of trade turnover between Ukraine and the EU has been built. The specification of gravity model has been realized using information criteria. It has been confirmed that the model is statistically significant, adequately describes the input data, and can be used for modelling and forecasting of foreign trade between other partners, taking into account the impact of specific institutional factors on their foreign trade relations.

\section{References:}

Baier, S., \& Bergstrand, J. (2009). Bonus vetus OLS: A Simple Method for Approximating International Trade-cost Effects. Journal of International Economics, 77(1), 77-85. (in English)

International Monetary Fund. (n.d.) imf.org. Retrieved from: http://www.imf.org/external/index.htm (in English) IndexMundi. (n.d.) indexmundi.com. Retrieved from: http://www.indexmundi.com/commodities/?commodity= crude-oil-brent (In English)

Konchyn, V., Lozhachevska, A. (2012). Zony vilnoi torhivli ta multyhravitatsiina rehionalna torhovelna model Ukrainy: perspektyvy rozvytku [Free trade and Ukraine's multi gravity regional trade model: development prospects]. Stratehiia rozvytku Ukrainy, 2, 85-106. (in Ukrainian)

Korovaichenko, N., Shevchenko, L. (2015). Vplyv vnutrishnikh ta zovnishnikh shokiv na rozvytok torhivli Ukrainy z FRN [The impact of domestic and external shocks on trade between Ukraine and Germany]. Zovnishnia torhivlia: ekonomika, finansy, pravo, 3(80), 81-89. (in Ukrainian)

Linnemann, H. (1967). Econometric Study of International Trade Flows. The Economic Journal, 77(306), $366-368$. (in English) 
McCallum, J. (1995). National Borders Matter: Canada-U.S. Regional Trade Patterns. The American Economic Association, 85(3), 615-623. (in English)

Nasadiuk, I. (2012). Hravitatsiina model mizhnarodnykh ekonomichnykh vidnosyn Ukrainy [Gravity model of Ukraine's international economic relations]. Visnyk sotsialno-ekonomichnykh doslidzhen, 1(44), 94-99 (in Ukrainian) Ofitsiinyi sait Derzhavnoi sluzhby statystyky Ukrainy [State Statistics Service of Ukraine]. (n.d.) ukrstat.org. Retrieved from: https://ukrstat.org/operativ/operativ2005/zd/zd_rik/zd_r/gs_r.html (in Ukrainian)

Poliakova, O., Shlykova, V. (2014). Modeliuvannia zmin zovnishnotorhovelnykh zviazkiv u konteksti rozshyrennia Yevropeiskoho Soiuzu [Simulation changes of trade relations in the context of EU enlargement]. Problemy ekonomiky, 1, 330-336 (in Ukrainian)

Podorozhnii, Y., Boldizhar, S. \& Sofilkanuch, O. (2018). Formation of European integration development strategy of Ukraine, Baltic Journal of Economic Studies, 4(1), 283-292. (in English)

Pryhodko, I. (2017). Theories of spatial economics in terms of economic integration, Baltic Journal of Economic Studies, 3(5), 376-382. (in English)

Tinbergen, J. (1966). Shaping the World Economy: Suggestions for an International Economic Policy. The Economic Journal, 76(301), 92-95. Retrieved from: http://www.jstor.org/stable/2229041 (in English) 